\title{
ESTIMATION OF STREPTOMYCIN AND PENICILLIN IN BLOOD
}

\author{
BY \\ W. A. GILLESPIE AND V. G. ALDER \\ From the Bristol Royal Hospital (Infirmary Branch)
}

(RECEIVED FOR PUBLICATION, APRIL 14, 1948)

The method here described, which we have been using for some time in routine work, is a modification of the micro-method of May and others (1947), in which dilutions of the patient's serum are added to phenol-red-serum water on waxed slides, and incubated in capillary tubes.

The dilutions of patient's serum and their addition to the medium are performed on a waxed glass plate which is incubated directly, without filling the mixtures into capillary tubes and fixing to plasticine-covered slides. In this way the amount of manipulation is reduced and an appreciable saving of time is achieved, especially when several sera are being titrated at the same time. Moreover the colour change at the end point is even more obvious than in capillaries and there is no danger of upsetting the tests by rough handling.

\section{Details of Method}

The medium used is 1 per cent glucose in a mixture of serum 1 part, distilled water 4 parts, sterilized by steaming (May and others, 1947). We find it best to make up batches of this medium without indicator. A saturated solution of phenol red in distilled water is put up separately in small amounts, each sufficient for one batch of medium, and similarly sterilized. At the time of the test the indicator is added in the proportion of about $0.05 \mathrm{ml}$. to $1 \mathrm{ml}$. serum water. We have found that if the indicator is added to the medium some days before use, fading occurs and the colour changes after incubation are not so distinct. The medium is inoculated as in the original method $(0.01 \mathrm{ml}$. of 24 -hour broth culture of the test organism to $1 \mathrm{ml}$. medium).

The capillary pipettes used to measure unit volumes have tapered, slightly angled free ends; as in the original method, they are graduated to contain $0.025 \mathrm{ml}$.

For making and incubating the dilutions, waxed rectangular slabs of glass, in which are drilled a series of depressions, are used. The slabs are cut from plate glass, about $7 \mathrm{~mm}$. thick, and measure approxi- mately $7.5 \times 4.5 \mathrm{~cm}$. In one surface of each slab are drilled ten circular depressions $8 \mathrm{~mm}$. in diameter and about $2 \mathrm{~mm}$. deep at the centre: Each plate is placed in a $3 \frac{1}{2}$-in. Petri dish and sterilized in hot air. When cool it is grasped with sterile forceps and $\stackrel{\rho}{\rightarrow}$ quickly dipped in melted sterile paraffin wax at about $\vec{\bullet}$ $60^{\circ} \mathrm{C}$., briefly drained, and replaced in its dish.

Serial dilutions of the patient's serum and of a suitable standard solution of antibiotic in normal serum are made in equal volumes of sterile saline in the depressions (with the last as a control). To each is added an equal volume of inoculated medium. A quantity of water or of moistened filter paper is $\mathbb{Q}$ placed in the Petri dish, which is incubated, lid upwards, at $37^{\circ} \mathrm{C}$. During incubation the dish shouldo rest on wood or other heat-insulating material to avoid moisture condensation on the lid.

For streptomycin estimations we use klebsiella 41 ? as test organism and inactivate the patient's serum. For penicillin, the Oxford staphylococcus is used. As: in the original method, it is advisable to aim at having 3 the end point within the first five or six dilutions in order to minimize the cumulative error of the wash.

After incubation, the last dilution showing complete inhibition is taken as the end point. The윽 strength of antibiotic is calculated by comparison with the standard. The drops of fluid retain theiro convex surfaces in the waxed depressions, thus rendering colour differences more striking; there is no ten- $\mathcal{O}$ dency for them to overflow, even with quite rough $N$ handling (Plate IX).

Numerous titrations have been done in parallelo with the capillary tube method, without significante differences in results.

Recently we have found (Goslings, 1947) an $\stackrel{?}{+}$ account of an essentially similar method for peni- 0 cillin, using hàemolytic streptococcus, with blood $\stackrel{0}{\circ}$ as the indicator.

\section{REFERENCES}

Goslings, W. R. O. (1947). Ned. Tijdschr. Geneesk., 01, 1542. (Abstract 67 in Abstracts of World Medicine, 3, January, 1948.) May, J. R., Voureka, A. E., and Fleming, A. (1947). Brit. med. J., $\mathbf{1 ,} 627$. 


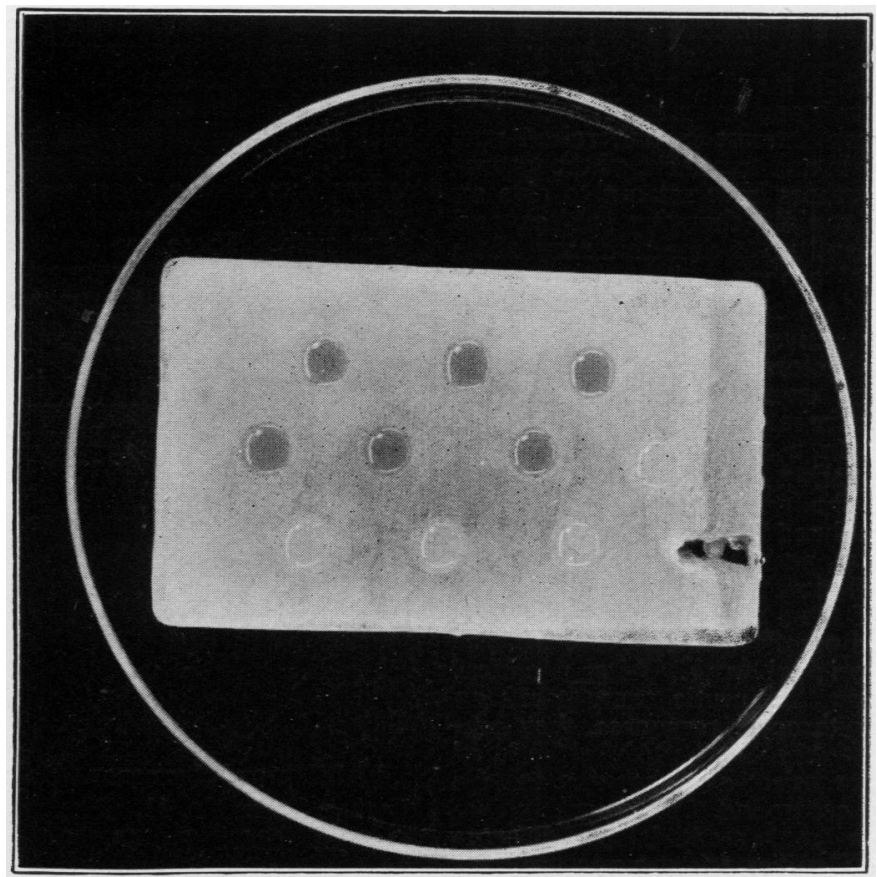

Plate IX.-Waxed depression plate after incubation. End point at dilution 1/64. 